\title{
Reviewer Acknowledgements for English Linguistics Research, Vol. 10, No. 3
}

English Linguistics Research (ELR) would like to acknowledge the following reviewers for their assistance with peer review of manuscripts for this issue. Many authors, regardless of whether ELR publishes their work, appreciate the helpful feedback provided by the reviewers. Their comments and suggestions were of great help to the authors in improving the quality of their papers. Each of the reviewers listed below returned at least one review for this issue.

\section{Reviewers for Volume 10, Number 3}

\author{
Alina Andreea Dragoescu Urlica, University of Life Sciences, Romania \\ Neda Chepinchikj, University of New South Wales (UNSW), Australia \\ Peace Chinwendu Israel, University of Education, Ghana \\ Yuehai Xiao, Hunan Normal University, China \\ Yuemin Wang, University of Chinese Academy of Sciences, China
}

Best Regards,

Camille $\mathrm{Su}$

Editorial Assistant, English Linguistics Research

Sciedu Press

******************************************

Add: 9140 Leslie St. Suite 110, Beaver Creek, Ontario, L4B 0A9, Canada

Tel: $1-416-479-0028$ ext. 210

Fax: 1-416-642-8548

E-mail 1: elr@sciedupress.com

E-mail 2: elr@sciedupress.org

Website: http://elr.sciedupress.com 